\title{
Synthesis and Light Induced Characteristics of Siloxane Substituted Azobenzene: An Application for Optical Storage Device
}

\author{
A. R. Yuvaraj, Md. Lutfor Rahman, and Mashitah Mohd Yusoff \\ Faculty of Industrial Sciences and Technology, Universiti Malaysia Pahang, 26300 Gambang, Kuantan, Malaysia \\ Correspondence should be addressed to Md. Lutfor Rahman; lutfor73@gmail.com
}

Received 14 November 2015; Revised 20 February 2016; Accepted 22 February 2016

Academic Editor: Hans Riesen

Copyright (C) 2016 A. R. Yuvaraj et al. This is an open access article distributed under the Creative Commons Attribution License, which permits unrestricted use, distribution, and reproduction in any medium, provided the original work is properly cited.

\begin{abstract}
The light induced behaviour of siloxane substituted azobenzene compounds in the presence of alkylene spacers is reported for the first time. Firstly, these photosensitive compounds were synthesized and elucidated the molecular structure by spectral analysis such as NMR, FTIR, and UV/Vis. Photoisomerization effect was evaluated in solution and also in nematic phase. The photosaturation occurred exactly at 29 seconds, whereas thermal back relaxation was observed ranging from 19.8 to 23.8 hours. Long duration of the thermal back relaxation is due to the presence of sterically hindered siloxane group substituted to the azobenzene molecules. Decrease in the duration of cis-trans isomerization was found when the number of alkylene spacers was increased. These siloxane based azobenzene derivatives are useful for the fabrication of optical storage device and molecular switches.
\end{abstract}

\section{Introduction}

The data can be optically stored by a device with the influence of suitable light. The phenomenon is called optical storage and the gadget is known as optical storage device [1]. Many photosensitive organic compounds have been employed to fabricate the optical storage device [1-4]. Mainly, performance of the optical storage device is based on the nature of chemical structure [4] and functional group [2] of the organic compounds which are used. Also the properties of illuminated light [5] are another important factor which gives impact in the device capabilities. However, the chromophoric functional groups are responsible for the isomerization [6] and molecular reorientation [7]. Azobenzene is a good candidate to study the photo-induced effects among other light sensitive compounds and this is due to the excellent photo-active behaviour of azobenzene chromophores [7]. The molecular structure of azobenzene facilitated the delocalization of $\pi$ electrons and lone pair of electrons between the acceptor and donor functional groups [8]. One of the important features of azobenzene is trans-cis isomerization. So many researchers reported the light induced effects and liquid crystal properties of azobenzene derivatives [6, 9-11].
Mainly, azobenzene compounds have great importance in liquid crystal research $[4,12,13]$ and the special characteristics of azobenzene can be employed in many areas of research such as photoalignment $[14,15]$, holographic media [16, 17], and optical storage $[18,19]$. Moreover, some of the azo dyes are not liquid crystals in nature. But most of the azo dyes which show photoisomerization can be used in guest-host system $[20,21]$. It means that the guest azobenzene derivatives can mix with host liquid crystal compounds and the light induced properties can be analysed. However, alkyl chains affect the photoisomerization of azobenzene derivatives in a significant extent [22-24].

Generally, light induced properties of azobenzene differ with varieties of structure, spacers, and functional group associated with it. Mainly, optical activity depends on the number of alkylene spacers present in the molecular structure [22-24]. Recently, the photoisomerization of azobenzene with aliphatic and aromatic spacers was also reported [8]. Therefore, the cis-trans isomerization of azobenzene with spacers is quite interesting to study. Azobenzene has trans configuration at room temperature and normal conditions [6]. Thermodynamically more stable trans form isomerizes to give cis form, when UV light of suitable wavelength 
is illuminated on the system of molecules [7]. Then, cis isomers comes back to the original state (trans isomeric form) spontaneously in most of the cases and the process is known as thermal back relaxation [6]. Even back relaxation phenomenon is fast, when exposing white light (say wavelength of $450 \mathrm{~nm}$ ). However, the functional group effects the photoisomerization process of azobenzene in a significant extent $[25,26]$. Particularly, organosilicon has peculiar contribution with azobenzene moiety in light induced studies.

Organosilicons are the derivatives of silane $\left(\mathrm{SiH}_{4}\right)$. Generally, silane is spontaneously flammable and hydrolyses rapidly with atmospheric moisture [27]. Electronegativity of the silicon (1.64) is less than carbon (2.35) and hydrogen (2.79). In other words, silicon is more electropositive than carbon. Hence, Si-H bond is more polar than $\mathrm{C}-\mathrm{H}$ bond. The covalent radius of silicon $(177 \mathrm{pm})$ is bigger than carbon $(77 \mathrm{pm})$. So nucleophile can attach silicon nucleus more easily than carbon [27]. Therefore, silicon derivatives are extensively synthetic chemistry to follow the simple and easy synthetic pathways [28]. Mainly, synthesis of organosilicon has great importance in material chemistry research, due to the thermal and electrical conductivity of silicon derivatives [29]. However, organosilicon has great role in several research areas, such as fluorescent chemosensing [30], antimicrobial activity [31], organometallic synthesis [32], medicinal chemistry [33], liquid crystals [29, 34-36], and electronics and photonics [29]. Liquid crystal properties of siloxane substituted azobenzene play main role in the liquid crystal display (LCD) research. Several liquid crystal phases were identified and characterized from the siloxane substituted azobenzene compounds [29, 34-36]. However, siloxane substituted azobenzene derivatives are interesting to evaluate the morphologies of $\mathrm{N}=\mathrm{N}$ photoisomerization.

The azobenzene derivatives are sterically hindered by bulky siloxane group [37, 38]. Thus, photoisomerization of $\mathrm{N}=\mathrm{N}$ in the molecular structure shows significant effect in presence of siloxane substitution [37]. Along with this, variable spacers (alkyl chains) are present in between siloxane and azobenzene moieties. Tacitly, our interest is to evaluate the effect caused by alkyl chains in the photoisomerization of siloxane substituted azobenzene derivatives. In this work, we have investigated the photoisomerization of siloxane substituted azobenzene with various alky spacers between siloxane and azobenzene moieties. This might show dramatic optical activities because of the spacers and bulky siloxane substitution.

\section{Experimental}

2.1. Raw Materials and Instruments Used. The materials include ethyl-4-aminobenzoate (Fluka), sodium nitrite (Aldrich), hydrochloric acid (Fluka), sodium hydroxide (Fluka), methanol (Fluka), phenol (Aldrich), 4-bromo-1-butene (Fluka), 5bromo-1-pentene (Fluka), 6-bromo-1-hexene (Fluka), potassium carbonate (Aldrich), potassium iodide (Aldrich), acetone (Fluka), potassium hydroxide (Aldrich), toluene (Fluka), Karstedt's catalyst (Aldrich), and 1,1,1,3,5,5,5-heptamethyltrisiloxane (Aldrich). Acetone was dried over phosphorus pentoxide (Fluka) and dichloromethane was dried over calcium hydride (Fluka) and distilled out before the use. Other solvents and chemicals were used as such.

Instrumental details are as follows. IR spectra were recorded using a Perkin Elmer (670) FTIR spectrometer. ${ }^{1} \mathrm{H}$ NMR $(500 \mathrm{MHz})$ and ${ }^{13} \mathrm{C}$ NMR $(125 \mathrm{MHz})$ were recorded in Bruker. The photoswitching study was performed using UVvisible spectrophotometer from Ocean Optics (HR2000+). For photoswitching studies in solutions, the compounds were dissolved in chloroform at fixed concentration of $C=1.1 \times$ $10^{-5} \mathrm{~mol} \mathrm{~L}^{-1}$. Photoisomerization of these compounds was investigated by illuminating it with an OmniCure S2000 UV source equipped with a $365 \mathrm{~nm}$ filter and heat filter was used to avoid unwanted heat from the radiation. The intensity used for measuring $E / Z$ is around $5.860 \mathrm{~mW} / \mathrm{cm}^{2}$ measured using UV meter. The absorption spectra were taken in both solutions and solid state for all the synthesized compounds. The photoswitching behaviour of these compounds was studied by shining UV light of suitable wavelength. Mesomorphic properties were investigated using polarized optical microscopy (Nikon, Olympus BX 51 POL) along with Linkam hotstage.

2.2. Synthesis and Elucidation. The siloxane substituted azobenzene derivatives ( $\mathbf{V a}-\mathbf{V c}$ ) can be synthesized by five steps. Firstly, 4-ethyl aminobenzoate was diazotized using sodium nitrite in the presence of acid medium. Then, the diazonium ion (I) produced in the first step was coupled by phenol to get II. Next, free hydroxyl group of the compound II was methylated with bromo-alkene in the presence of mild basic medium. On the other hand, the substituted ester group was hydrolysed using potassium hydroxide and water. Lastly, the carboxylic acid group which is present in IVaIVc was further treated with siloxane derivative. The synthetic strategy is given in Scheme 1.

2.2.1. General Procedure for Diazotization of Aniline Derivative (II). The solution of 4-ethyl amino benzoate $(7.59 \mathrm{~g}$, $46.00 \mathrm{mmol})$ was prepared by methanol $(40 \mathrm{~mL})$ and cooled to $0-2^{\circ} \mathrm{C}$. $25 \% \mathrm{HCl}$ was added dropwise to the solution at $2^{\circ} \mathrm{C}$. The solution of sodium nitrite $(3.03 \mathrm{~g}, 44.6 \mathrm{mmol})$ was prepared in water and added to the reaction mixture dropwise at $2^{\circ} \mathrm{C}$ for 15 minutes. Then, phenol $(4.19 \mathrm{~g}, 44.6 \mathrm{mmol})$ was dissolved in methanol and slowly added to the reaction mixture at $2^{\circ} \mathrm{C}$. Next, $1 \mathrm{~N} \mathrm{NaOH}$ solution was added to the reaction mixture to increase the $\mathrm{pH}$ (around 8.5-9.0) and reaction mixture was stirred for 4 hours. Finally, the reaction mixture was poured into the beaker containing crushed ice with methanol $(250 \mathrm{~mL})$. The solution was filtered to collect the reddish brown precipitate and it was dried and recrystallized with methanol. A red coloured solid; yield: $82 \%$; melting point: $160.2-160.5^{\circ} \mathrm{C}$; IR (KBr Pellet) $v_{\max }$ in $\mathrm{cm}^{-1}: 3321(\mathrm{OH})$, 1728 ( C=O, ester), 1602, 1484 ( $\mathrm{C}=\mathrm{C}, \mathrm{Ar}), 1248,1140$ (C-O, Ar), $829(\mathrm{Ar}-\mathrm{H}) ;{ }^{1} \mathrm{H}$ NMR $(500 \mathrm{MHz}$, acetone-d6): $\delta 8.17(\mathrm{~d}, J=$ $8.2 \mathrm{~Hz}, 2 \mathrm{H}, \mathrm{Ar}$ ), 7.92 (d, $J=7.5 \mathrm{~Hz}, 2 \mathrm{H}, \mathrm{Ar}), 7.88$ (d, $J=7.5 \mathrm{~Hz}$, $2 \mathrm{H}, \mathrm{Ar}), 7.01$ (d, $J=8.2 \mathrm{~Hz}, 2 \mathrm{H}, \mathrm{Ar}), 5.54$ (s, 1H, OH), 4.42 (q, $\left.J=7.2 \mathrm{~Hz}, 2 \mathrm{H}, \mathrm{OCH}_{2}\right), 1.44\left(\mathrm{t}, 3 \mathrm{H}, \mathrm{CH}_{3}\right)$.

2.2.2. General Procedure to Alkylate the Phenyl Group of Azo Dye (IIIa-IIIc). The solution of II $(4.77 \mathrm{~g}, 18.5 \mathrm{mmol})$ 
<smiles>CCOC(=O)c1ccc(N)cc1</smiles><smiles>C=CCCCC(C)(C)OC(C)=O</smiles><smiles>C=CCOc1ccc(N=Nc2ccc(C(=O)OCC)cc2)cc1</smiles><smiles>C=CCOc1ccc(N=Nc2ccc(C(=O)O)cc2)cc1</smiles><smiles>C[Si](C)(C)O[Si](C)(CCOc1ccc(N=Nc2ccc(C(=O)O)cc2)cc1)O[Si](C)(C)C</smiles>

Scheme 1: Synthetic scheme for halogen substituted azo dyes.

and 6-bromo-1-hexene $(6.12 \mathrm{~g}, 37.1 \mathrm{mmol})$ was prepared by acetone $(30 \mathrm{~mL})$. The catalytic amounts of potassium iodide $(50 \mathrm{mg})$ and also potassium carbonate $(2.55 \mathrm{~g}, 18.5 \mathrm{mmol})$ were added to the reaction portionwise and refluxed. The reaction mixture was monitored during the reflux by TLC. After 24 hours, the reaction mixture containing IIIa was dried and used for the next step. The similar procedure was followed to synthesize IIIb-IIIc.

2.2.3. General Procedure to Hydrolyse the Ester of Azo Dye $(\boldsymbol{I V a}-\boldsymbol{I V} \boldsymbol{c})$. Dried precipitate (IIIa) from the previous step was dissolved in methanol $(100 \mathrm{~mL})$ and the solution of potassium hydroxide $(3.48 \mathrm{~g}, 62.2 \mathrm{mmol})$ in water $(20 \mathrm{~mL})$ was added dropwise. The reaction mixture was refluxed for four hours and the completion of the reaction was confirmed by
TLC. Then, the reaction mixture was washed with $n$-hexane to remove the nonpolar impurities. Dilute $\mathrm{HCl}$ was added to the crude solution until the $\mathrm{pH}$ of the solution becomes 6 . The compound was extracted with ethyl acetate and brine wash was given to remove ionic impurities. The crude solution was dried over anhydrous sodium sulphate and solvent was removed by rotor vapour. The crude solid (IVa) obtained was recrystallized by methanol. A dark yellow coloured solid; yield: $75 \%$; melting point is $153.2-153.6^{\circ} \mathrm{C}$; IR ( $\mathrm{KBr}$ Pellet) $v_{\max }$ in $\mathrm{cm}^{-1}: 3380(\mathrm{OH}), 2942,2840\left(\mathrm{CH}_{2}\right), 1681(\mathrm{C}=\mathrm{O}$, acid), 1600, 1421 (C=C, Ar), 1289, 1248 (C-O, Ar), $837\left(\right.$ Ar-H); ${ }^{1} \mathrm{H}$ NMR (500 MHz, DMSO): $\delta 8.12(\mathrm{~d}, J=8 \mathrm{~Hz}, 2 \mathrm{H}, \mathrm{Ar}), 7.93$ (d, $J=7.65 \mathrm{~Hz}, 2 \mathrm{H}, \mathrm{Ar}), 7.91(\mathrm{~d}, J=7.5 \mathrm{~Hz}, 2 \mathrm{H}, \mathrm{Ar}), 7.14$ (d, $J=$ $7.2 \mathrm{~Hz}, 2 \mathrm{H}, \mathrm{Ar}), 4.22\left(\mathrm{t}, J=4.3 \mathrm{~Hz}, 2 \mathrm{H}, \mathrm{OCH}_{2}\right), 5.85-5.93(\mathrm{~m}$, $3 \mathrm{H}$, olefinic), 1.73 (q, 2H, $\mathrm{CH}_{2}$ ). 
2.2.4. General Procedure to Silylation of the Olefinic Group Substituted Azo Dye (Va-Ve). IVa $(0.25 \mathrm{~g}, 0.84 \mathrm{mmol})$ and 1,1,1,3,3,5,5-heptamethyltrisiloxane $(0.18 \mathrm{~g}, 0.84 \mathrm{mmol})$ were dissolved in $4 \mathrm{~mL}$ of toluene. Catalytic amount of Karstedt's catalyst was added to the solution. The reaction mixture was stirred for 2 days at room temperature and the completion of reaction was monitored by TLC. The solvent was evaporated under the fume-hood after completion of the reaction. Next, crude product Va was purified by column chromatography using chloroform as mobile phase. The dark yellow compound was recrystallized using chloroform $\left(R_{f}\right.$ $=0.18)$. The compounds $\mathbf{V b}-\mathbf{V c}$ were synthesized according to the procedure described for Va. The representative ${ }^{1} \mathrm{H}$, ${ }^{13} \mathrm{C}$ NMR, and IR spectra are given in the supplementary information (Figure S1, S2, and S3 in Supplementary Material available online at http://dx.doi.org/10.1155/2016/4715230).

Va: a dark yellow coloured solid; yield: $46 \%$; melting point is $118.2-118.9^{\circ} \mathrm{C}$; IR ( $\mathrm{KBr}$ Pellet) $v_{\max }$ in $\mathrm{cm}^{-1}: 3416$ $(\mathrm{OH}), 2922,2850\left(\mathrm{CH}_{2}\right), 1683(\mathrm{C}=\mathrm{O}$, acid $), 1599,1500(\mathrm{C}=\mathrm{C}$, Ar), $1418\left(\mathrm{CH}_{3}\right), 1295,1250$ (C-O, Ar), $839(\mathrm{Ar}-\mathrm{H}) ;{ }^{1} \mathrm{H}$ NMR (500 MHz, DMSO): $\delta 8.21$ (d, $J=8 \mathrm{~Hz}, 2 \mathrm{H}, \mathrm{Ar}), 7.95(\mathrm{~d}, J=$ $7.65 \mathrm{~Hz}, 2 \mathrm{H}, \mathrm{Ar}), 7.93(\mathrm{~d}, J=7.5 \mathrm{~Hz}, 2 \mathrm{H}, \mathrm{Ar}), 7.03(\mathrm{~d}, J=7.2 \mathrm{~Hz}$, $2 \mathrm{H}, \mathrm{Ar}), 4.07\left(\mathrm{t}, J=4.37 \mathrm{~Hz}, 2 \mathrm{H}, \mathrm{OCH}_{2}\right), 2.23\left(\mathrm{q}, 2 \mathrm{H}, \mathrm{CH}_{2}\right)$, $1.48\left(\mathrm{q}, 2 \mathrm{H}, \mathrm{CH}_{2}\right), 1.29\left(\mathrm{~s}, 3 \mathrm{H}, \mathrm{CH}_{3}\right), 0.97\left(\mathrm{~s}, 3 \mathrm{H} \times 6, \mathrm{CH}_{3}\right)$.

Vb: a dark yellow coloured solid; yield: $46 \%$; melting point is $124.3-124.8^{\circ} \mathrm{C}$; IR ( $\mathrm{KBr}$ Pellet) $v_{\max }$ in $\mathrm{cm}^{-1}: 3410$ $(\mathrm{OH}), 2920,2844\left(\mathrm{CH}_{2}\right), 1678(\mathrm{C}=\mathrm{O}$, acid $), 1600,1500(\mathrm{C}=\mathrm{C}$, Ar), $1423\left(\mathrm{CH}_{3}\right), 1247,1140$ (C-O, Ar), 837 (Ar-H). ${ }^{1} \mathrm{H}$ NMR (500 MHz, DMSO): $\delta 8.21(\mathrm{~d}, J=8.1 \mathrm{~Hz}, 2 \mathrm{H}, \mathrm{Ar}), 7.95(\mathrm{~d}, J=$ $7.65 \mathrm{~Hz}, 2 \mathrm{H}, \mathrm{Ar}), 7.93$ (d, $J=7.5 \mathrm{~Hz}, 2 \mathrm{H}, \mathrm{Ar}), 7.03$ (d, $J=7.2 \mathrm{~Hz}$, $2 \mathrm{H}, \mathrm{Ar}), 4.07\left(\mathrm{t}, J=4.3 \mathrm{~Hz}, 2 \mathrm{H}, \mathrm{OCH}_{2}\right), 2.23\left(\mathrm{q}, 2 \mathrm{H}, \mathrm{CH}_{2}\right), 1.48$ $\left(\mathrm{q}, 2 \mathrm{H}, \mathrm{CH}_{2}\right), 1.39\left(\mathrm{q}, 2 \mathrm{H}, \mathrm{CH}_{2}\right), 1.29\left(\mathrm{~s}, 3 \mathrm{H}, \mathrm{CH}_{3}\right), 0.97(\mathrm{~s}, 3 \mathrm{H}$ $\left.\times 6, \mathrm{CH}_{3}\right)$.

Vc: a dark yellow coloured solid; yield: $46 \%$; melting point is $129.8-130.3^{\circ} \mathrm{C}$; IR (KBr Pellet) $v_{\max }$ in $\mathrm{cm}^{-1}: 3417$ $(\mathrm{OH}), 2935,2848\left(\mathrm{CH}_{2}\right), 1679(\mathrm{C}=\mathrm{O}$, acid), 1600, $1500(\mathrm{C}=\mathrm{C}$, Ar), $1422\left(\mathrm{CH}_{3}\right), 1247,1142$ (C-O, Ar), 838 (Ar-H). ${ }^{1} \mathrm{H}$ NMR (500 MHz, DMSO): $\delta 8.21(\mathrm{~d}, J=8.1 \mathrm{~Hz}, 2 \mathrm{H}, \mathrm{Ar}), 7.95(\mathrm{~d}, J$ $=7.65 \mathrm{~Hz}, 2 \mathrm{H}, \mathrm{Ar}), 7.93(\mathrm{~d}, J=7.5 \mathrm{~Hz}, 2 \mathrm{H}, \mathrm{Ar}), 7.03(\mathrm{~d}, J=$ $7.2 \mathrm{~Hz}, 2 \mathrm{H}, \mathrm{Ar}), 4.07\left(\mathrm{t}, J=4.3 \mathrm{~Hz}, 2 \mathrm{H}, \mathrm{OCH}_{2}\right), 2.23(\mathrm{q}, 2 \mathrm{H}$, $\left.\mathrm{CH}_{2}\right), 1.51\left(\mathrm{q}, 2 \mathrm{H}, \mathrm{CH}_{2}\right), 1.48\left(\mathrm{q}, 2 \mathrm{H}, \mathrm{CH}_{2}\right), 1.39\left(\mathrm{q}, 2 \mathrm{H}, \mathrm{CH}_{2}\right)$, $1.29\left(\mathrm{~s}, 3 \mathrm{H}, \mathrm{CH}_{3}\right), 0.97\left(\mathrm{~s}, 3 \mathrm{H} \times 6, \mathrm{CH}_{3}\right) ;{ }^{13} \mathrm{C} \mathrm{NMR}(100 \mathrm{MHz}$, Acetone-d6): $\delta 168(\mathrm{COOH}), 160,154,145,136,129,123,120$, $112,66\left(\mathrm{OCH}_{2}\right), 29,27,24,21,15,12$.

\section{Result and Discussion}

3.1. Photoswitching Properties. These azo bridged compounds consist of siloxane substitution at one side and carboxylic acid substitution at another side. Tacitly, these compounds were characterized using UV-Vis light to evaluate the photoswitching properties. The compounds Va-Vc were showing same absorption maxima at $357.91 \mathrm{~nm}$, due to their similar molecular structure. Photoisomerization studies were carried out for the siloxane substituted azobenzene derivatives by using solution of them and also with cell filled with nematic host-guest mixture. In case of liquid crystal cell, the commercial liquid crystal MLC 6873-100 was used as host, whereas

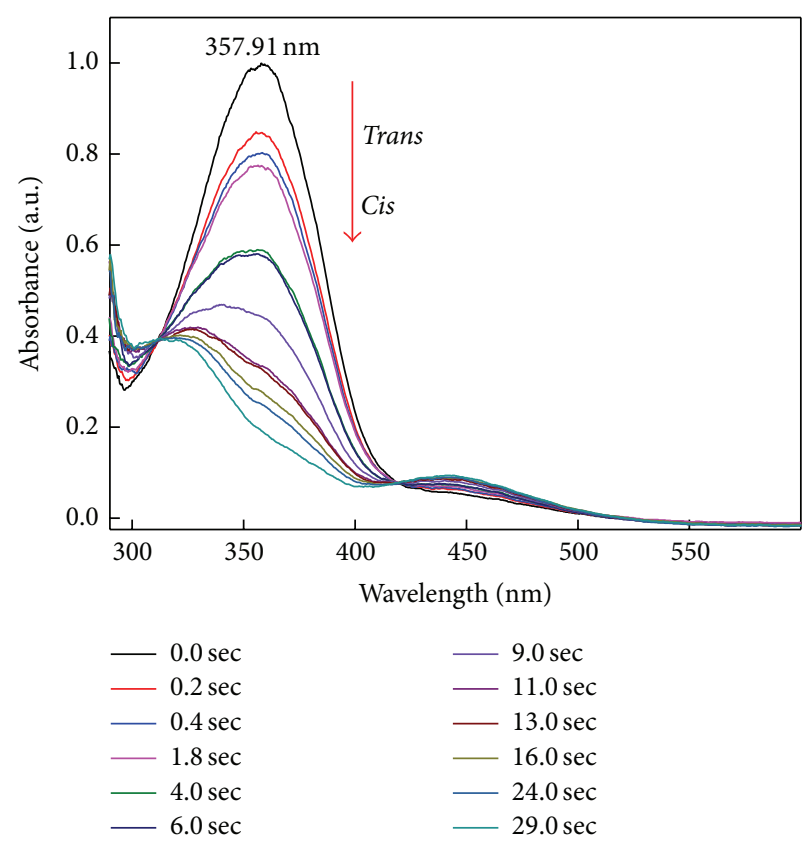

FIgURE 1: Trans to cis photoisomerization of Va with UV light irradiation.

Va was used as guest sample. The result obtained by the liquid crystal cell analysis supports the construction of optical storage device.

In photoisomerization of Va-Vc solutions, $5.8 \mathrm{~mW} / \mathrm{cm}^{2}$ UV-Vis intensity was used and the solution concentration was fixed at $1.1 \times 10^{-5} \mathrm{~mol} \mathrm{~L}^{-1}$. E-Z isomerization of $\mathbf{V a}-\mathbf{V c}$ was showed in Figure 1. The absorption maxima at $357.91 \mathrm{~nm}$ $\left(\lambda_{\max }\right)$ correspond to $\pi-\pi^{*}$ transition of trans isomer of the compounds at room temperature [9]. The absorption maxima decrease, when the UV-Vis light of wavelength $357 \mathrm{~nm}$ is illuminated on the system of molecules $[6,11,39,40]$. The process is called $E-Z$ isomerization or trans-cis isomerization. It means that the conversion of trans to cis form of the azobenzene molecule takes place during the irradiation of UV-Vis light of suitable wavelength. The absorption maxima go to the lower level and even absorption maxima disappear in most of the times at the stage of photosaturation $[2,31]$. The low level of the absorption maxima at photosaturation corresponds to cis isomeric form [6]. The photosaturation occurring for the compounds Va-Vc is 29 seconds (Figure 1).

The absorption of the solutions of $\mathbf{V a}-\mathbf{V c}$ with respect to the wavelength was considered and the graph was plotted (Figure 1). The curves show trans to cis isomerization of the compounds with the time interval of 29 seconds. The reverse process to trans to $c i s$ isomerization is called back relaxation or $Z$ to $E$ conversion [6,39]. Firstly, $Z$ to $E$ conversion can be achieved by irradiating the visible light of $450 \mathrm{~nm}$ wavelength. Secondly, keeping the solution or sample in dark place also resulted in trans to cis isomerization and it is known as thermal back relaxation process $[6,40]$. Usually, the solution or sample is illuminated with the UV light of suitable wavelength to get the photostationary state (to get 

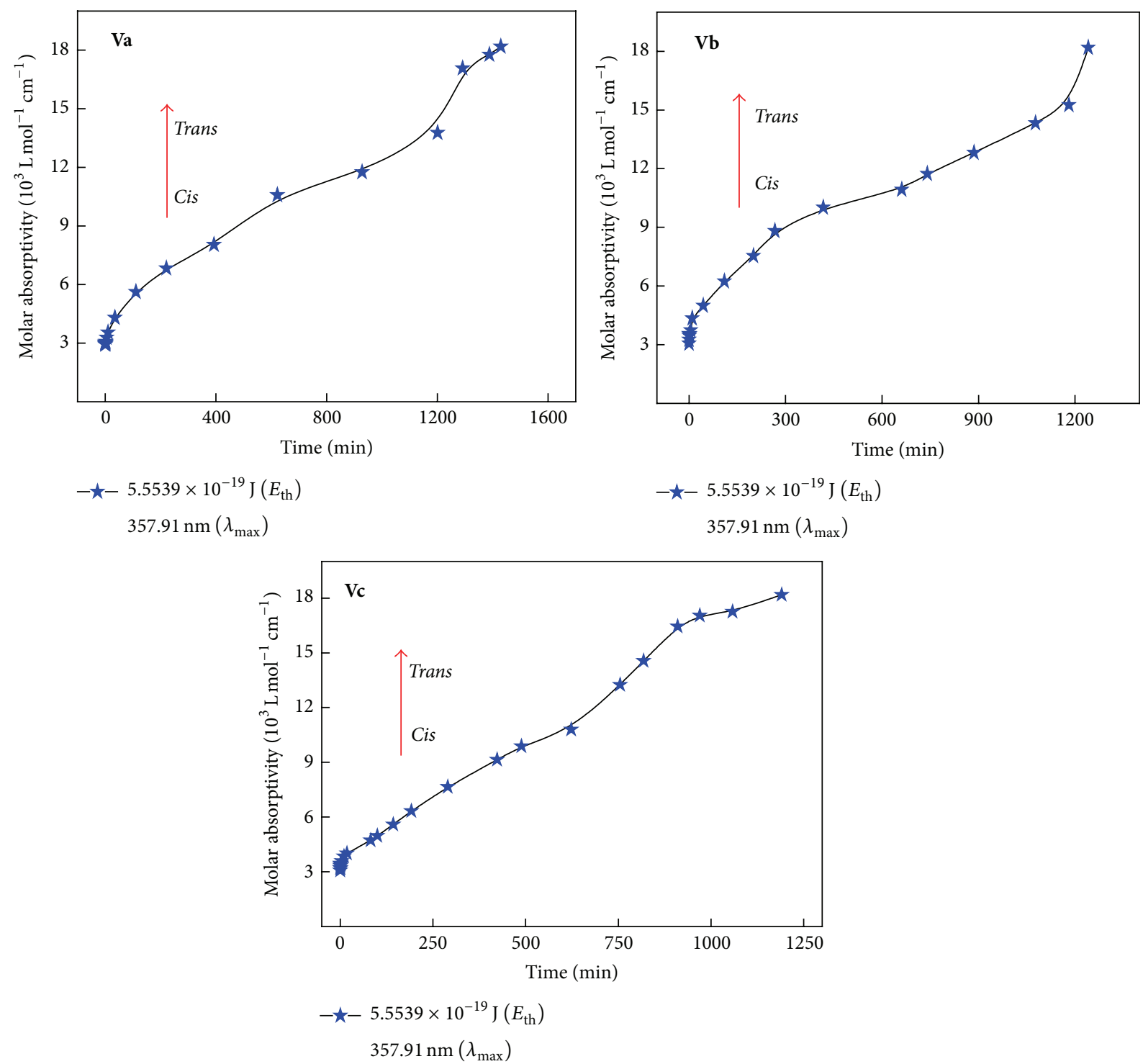

FIgURE 2: Thermal back relaxation of the compounds $\mathbf{V a}, \mathbf{V b}$, and $\mathbf{V c}$ after the photosaturation.

cis isomeric form) and kept in a dark place to study the absorption parameter in subsequent time interval.

Spectroscopic studies showed that thermal back relaxation of the compounds $\mathbf{V a}-\mathbf{V c}$ is $23.8,20.6$, and 19.8 hours, respectively (Figure 2). Additionally, the time interval was also recorded with respect to the absorbance at threshold energy of illuminated photons. Clearly, all the three siloxane substituted azobenzene derivatives showed different interval of thermal back relaxation due to the variation in number of alkyl chains $\left(\mathrm{CH}_{2}\right.$ units) or spacers. Hence, optical activity of the compounds depends on the presence of spacers associated with each molecule. Consequently, the long-time thermal back relaxation is because of the presence of siloxane moiety. Generally, photoswitching effect is significantly affected by steric hindrance of siloxane group. So variation in thermal back relaxation is due to steric hindrance and alkylene spacers, which are linked between azobenzene and siloxane moieties.

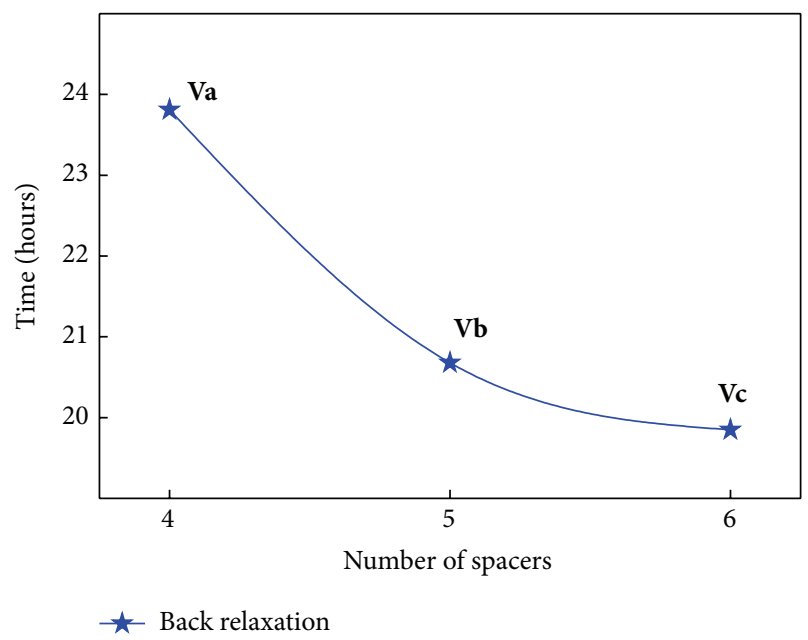

FIgURE 3: Comparison of thermal back relaxation with spacers. 


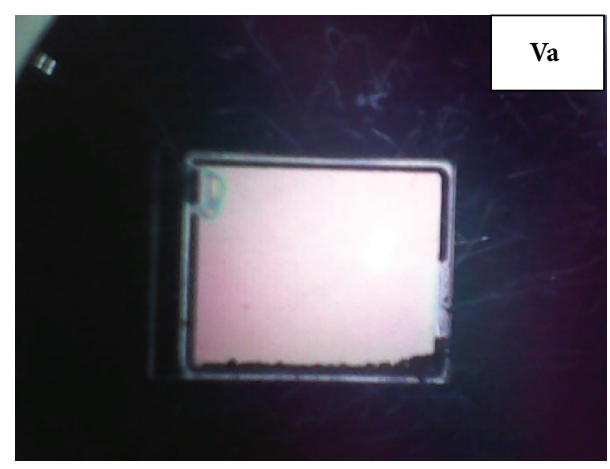

(a)

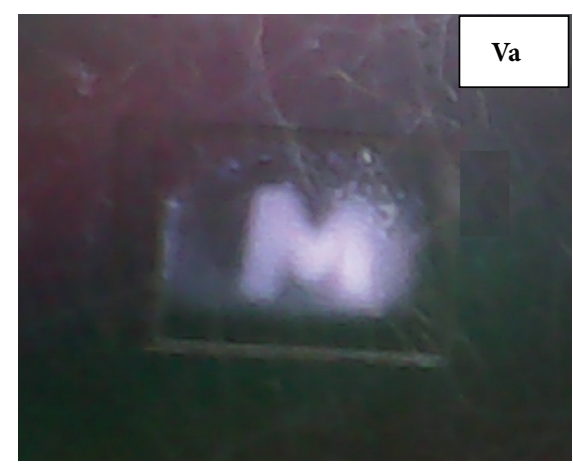

(b)

FIGURE 4: Fabricated optical storage device by using the compound Va: (a) before illuminating UV light and (b) after illuminating UV light with photomask.
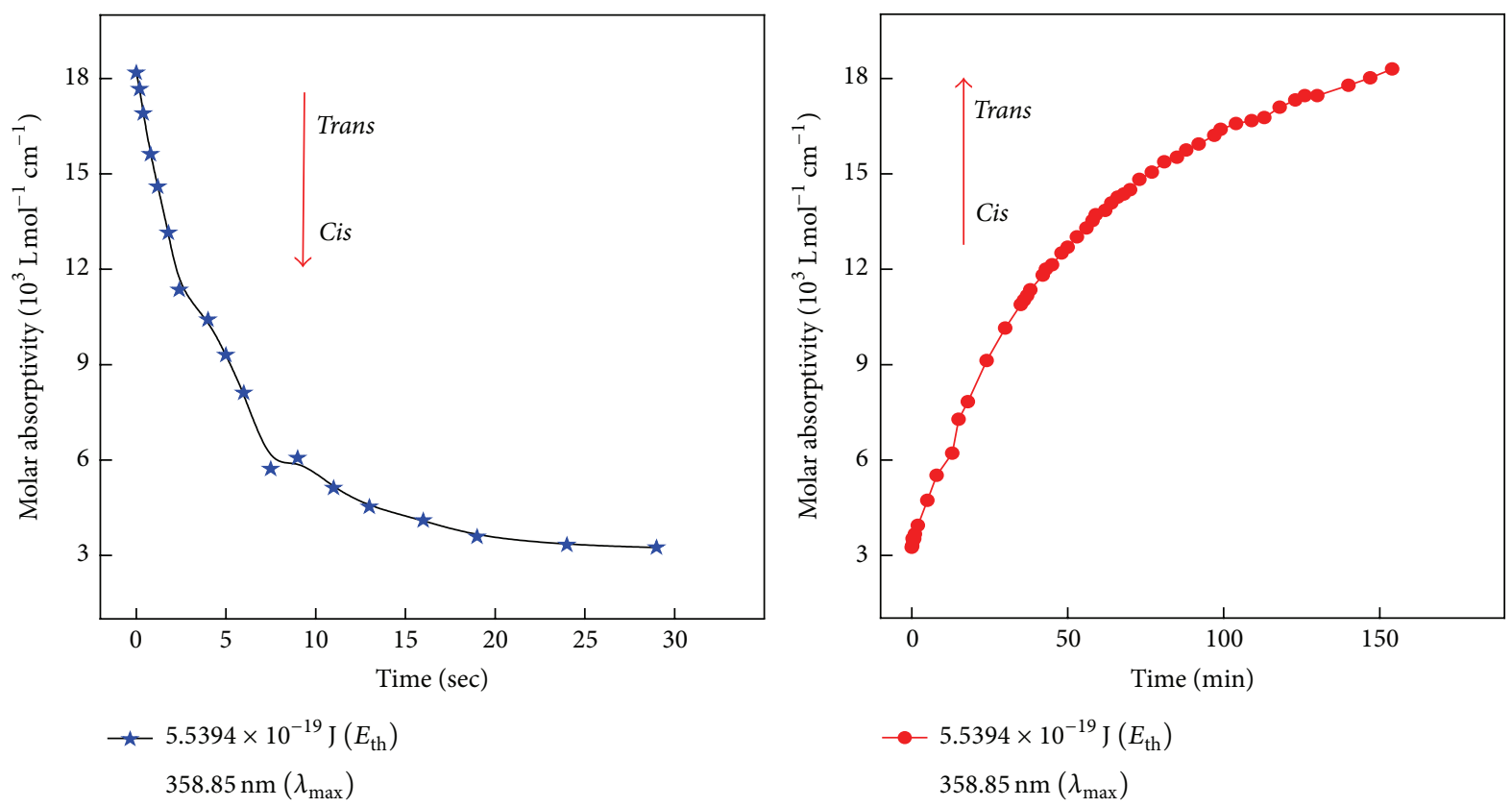

FIgURE 5: Photoisomerization of Va by using liquid crystal prototype cell.

Usually, the back relaxation decreases when the spacer length increases $[23,41,42]$. In this case also, thermal back relaxation was decreased with increasing the number of spacers present in the molecular structure of the compounds Va-Vc as shown in Figure 3. However, steric hindrance decreases when length of alkyl chain increases. So thermal back relaxation decreases with decrease in steric hindrance.

3.2. Optical Storage. Exactly $5 \%$ of Va was mixed with commercial liquid crystal MLC6873-100. The homogeneous mixture was eluted in the unidirectionally rubbed and polyimide coated cell. The mobility of the mixture follows the principle of capillary action. This liquid crystal cell (Figure 4) was irradiated with the UV light of intensity $5.860 \mathrm{~mW} / \mathrm{cm}^{2}$ and the absorption parameters were studied. The photosaturation occurred at 29 seconds for the liquid crystal prototype cell, which is same as photosaturation of $\mathbf{V a}-\mathbf{V c}$ in solutions and the reverse process ( $Z$ to $E$ isomerization) occurred at 154 minutes as shown in Figure 5.

In Figure 4, the first image was captured before illuminating the UV light on the prototype cell as shown in Figure 4(a). Then, UV light was irradiated on the same cell with the photomask " $\mathrm{M}$ " as shown in Figure 4(b). The letter " $\mathrm{M}$ " is masked portion (bright area) and it is protected from the UV radiation in the second image whereas the surrounded blank area is affected by the UV light irradiation.

The prototype of liquid crystal cell was prepared to prove the ability of the siloxane substituted azobenzene compound Va for the application of optical data storage device (Figure 4). The homogeneous mixture was prepared by dissolving 5\% of Va in MLC 6873-100 (commercial liquid crystal). The compound was losing its order when the UV light was illuminated on it. In other words, there is an order to disorder transition observed after illuminating the UV light 


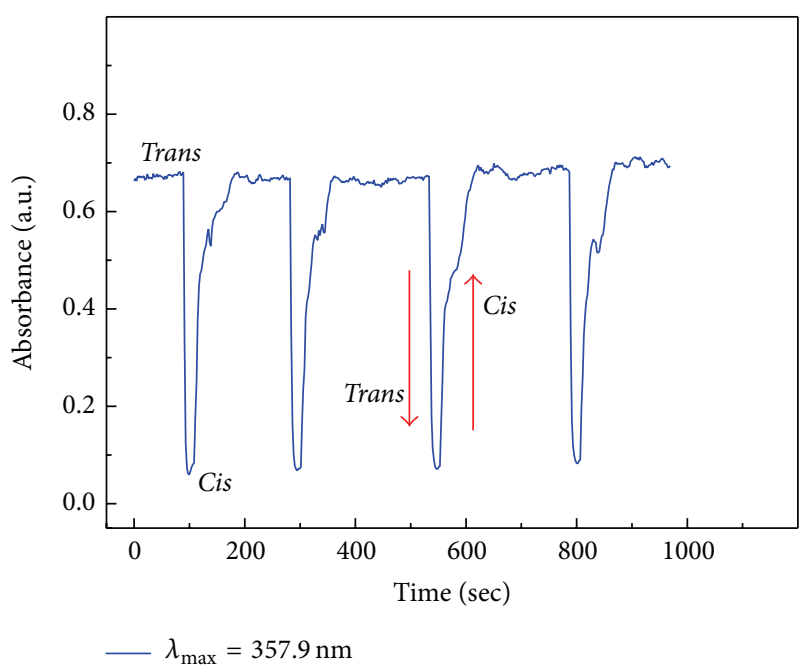

FIGURE 6: The determination of photostability of Va.

on the system [4], which was giving high contrast between dark and bright states through analyser. In Figure 4, dark portion corresponds to the illuminated area and bright portion corresponds to masked area. The ordered to disordered state transition is observed via UV light illumination. However, the chalcone derivatives were also synthesized and studied for the photoswitching behaviour to compare the photoreactivity of them with azo dyes.

Figure 6 shows the photostability of the compound Va. Multiple cycles of photoisomerization is considered here, irrespective of time of trans-cis and cis-trans isomerization. The compound Va is dissolved in chloroform with the concentration $1.1 \times 10^{-5} \mathrm{~mol} \mathrm{~L}^{-1}$. The UV light of intensity $10 \mathrm{~mW} \mathrm{~cm}^{-2}$ was illuminated on the solution continuously, until photostationary state. Immediately, visible light of $10 \mathrm{~mW} \mathrm{~cm}^{-2}$ (450 nm wavelength) was irradiated on the solution for back relaxation process after photosaturation state. This phenomenon was continued several times to evaluate the photostability of the compound. Thus, these compounds are stable towards light and do not degrade via light illumination. Also one can reuse the compound several times in the photoinduced process without discording the compound as a waste. Therefore, these siloxane substituted azo dyes are suitable in optical storage device industries, due to the excellent light induced characteristics. Mainly, industries may reduce the chemical wastes by the usage of these compounds.

\section{Conclusion}

Siloxane substituted azo dyes with various oligomethylene spacers being synthesized. These spacers play important role in the variation of cis-trans isomerization of azobenzene derivatives. Usually, spacers increase the flexibility of the organic molecules. The increase in flexibility enhances the free rotation and mobility of the molecules. However, these spacer substituted azobenzene compounds are suitable for photochromic studies under UV-Vis light irradiation. The trans-cis isomerization of these compounds is 29 seconds whereas the thermal back relaxations were 19.8-23.8 hours in solutions. However, the back relaxation was studied for the compound Va in solid state and it was 154 minutes. The long thermal back relaxation is mainly due to the presence of steric hindrance of siloxane group. The steric effect was reduced, when length of the alkyl chain was increased and time interval of thermal back relaxation also decreases accordingly. Compound Va was mixed with commercial liquid crystal and prepared the optical storage device prototype. The excellent storage properties were observed in the prototype cell. Also the photostability of these compounds was evaluated and these compounds showed the excellent photostability with the illumination of light (with high intensity) and the compounds were stable after many cycles of light illumination process. Therefore, siloxane substituted azobenzene connected with alkylene spacers can be very much useful in the fabrication of optical storage device and molecular switches.

\section{Competing Interests}

The authors declare that there are no competing interests.

\section{Acknowledgments}

This work was supported by FRGS grant obtained from Ministry of Education, Malaysia (no. 130121).

\section{References}

[1] R. Fernández, I. Mondragon, R. C. Sanfelice et al., "Optical storage in azobenzene-containing epoxy polymers processed as Langmuir Blodgett films," Materials Science and Engineering C, vol. 33, no. 3, pp. 1403-1408, 2013.

[2] C. García-Iriepa, M. Marazzi, L. M. Frutos, and D. Sampedro, "E/Z photochemical switches: syntheses, properties and applications," RSC Advances, vol. 3, no. 18, pp. 6241-6266, 2013.

[3] R. Hagen and T. Bieringer, "Photoaddressable polymers for optical data storage," Advanced Materials, vol. 13, no. 23, pp. 1805-1810, 2001.

[4] M. R. Lutfor, M. M. Yusoff, G. Hegde et al., "Synthesis of bananashaped liquid crystals for photoswitching properties," Molecular Crystals and Liquid Crystals, vol. 587, no. 1, pp. 41-53, 2013.

[5] S. N. Sidharth, A. R. Yuvaraj, T. J. Hui, B. K. Sarojini, M. Y. Mashitah, and G. Hegde, "Light induced properties of chalcones correlated with molecular structure and photophysical properties for permanent optical storage device," Advanced Materials Research, vol. 1033-1034, pp. 1149-1153, 2014.

[6] H. M. D. Bandara and S. C. Burdette, "Photoisomerization in different classes of azobenzene," Chemical Society Reviews, vol. 41, no. 5, pp. 1809-1825, 2012.

[7] H. M. D. Bandara, T. R. Friss, M. M. Enriquez et al., "Proof for the concerted inversion mechanism in the trans $\rightarrow$ cis Isomerization of azobenzene using hydrogen bonding to induce isomer locking," Journal of Organic Chemistry, vol. 75, no. 14, pp. 48174827, 2010.

[8] A. R. Yuvaraj, G. S. Mei, A. D. Kulkarni, M. Y. Mashitah, and G. Hegde, "Aliphatic/aromatic spacers based azo dye dimers: synthesis and application for optical storage devices," RSC Advances, vol. 4, no. 92, pp. 50811-50818, 2014. 
[9] T. Asano, T. Okada, S. Shinkai, K. Shigematsu, Y. Kusano, and O. Manabe, "Temperature and pressure dependences of thermal cis-to-trans isomerization of azobenzenes which evidence an inversion mechanism," Journal of the American Chemical Society, vol. 103, no. 17, pp. 5161-5165, 1981.

[10] R. S. Becker and K. J. Freedman, "A comprehensive investigation of the mechanism and photophysics of isomerization of a protonated and unprotonated Schiff base of 11-cis-retinal," Journal of the American Chemical Society, vol. 107, no. 6, pp. 1477-1485, 1985.

[11] A. A. Beharry and G. A. Woolley, "Azobenzene photoswitches for biomolecules," Chemical Society Reviews, vol. 40, no. 8, pp. 4422-4437, 2011.

[12] A. G. Cook, J. L. Wardell, N. J. Brooks, J. M. Seddon, A. Martínez-Felipe, and C. T. Imrie, "Non-symmetric liquid crystal dimer containing a carbohydrate-based moiety," Carbohydrate Research, vol. 360, pp. 78-83, 2012.

[13] P. Yeh and C. Gu, Optics of Liquid Crystal Displays, vol. 67, John Wiley \& Sons, New York, NY, USA, 2009.

[14] G. Hegde, R. A. Alla, A. Matharu, and L. Komitov, "Azo containing thiophene based prop-2-enoates for photoalignment of a nematic liquid crystal," The Journal of Materials Chemistry C, vol. 1, no. 22, pp. 3600-3605, 2013.

[15] O. Yaroshchuk, H. Gurumurthy, V. G. Chigrinov, H. S. Kwok, H. Hasebe, and H. Takatsu, "Photoalignment properties of brilliant yellow dye," in Proceedings of the 14th International Display Workshops (IDW'07), pp. 1665-1668, December 2007.

[16] M. Itoh, K. Harada, S.-I. Kamemaru, and T. Yatagai, "Holographic recording on azo-benzene functionalized polymer film," Japanese Journal of Applied Physics, vol. 43, no. 7, pp. 49684973, 2004.

[17] D. Y. Kim, S. K. Tripathy, L. Li, and J. Kumar, "Laser-induced holographic surface relief gratings on nonlinear optical polymer films," Applied Physics Letters, vol. 66, no. 10, pp. 1166-1168, 1995.

[18] G. Hegde, A. R. Yuvaraj, W. Sinn-Yam, and M. M. Yusoff, "Fast photoswitching azo dyes," Macromolecular Symposia, vol. 353, no. 1, pp. 240-245, 2015.

[19] A. R. Yuvaraj, W. S. Yam, T. N. Chan, Y. P. Goh, and G. Hegde, "New para-substituted non-symmetric isoflavones for their fast photo-switching ability: synthesis and their liquid crystal characterization," Spectrochimica Acta Part A: Molecular and Biomolecular Spectroscopy, vol. 135, pp. 1115-1122, 2015.

[20] M. R. Lutfor, G. Hegde, S. Kumar, C. Tschierske, and V. G. Chigrinov, "Synthesis and characterization of bent-shaped azobenzene monomers: guest-host effects in liquid crystals with azo dyes for optical image storage devices," Optical Materials, vol. 32, no. 1, pp. 176-183, 2009.

[21] T. Muraoka, K. Kinbara, and T. Aida, "Mechanical twisting of a guest by a photoresponsive host," Nature, vol. 440, no. 7083, pp. 512-515, 2006.

[22] G. S. Kumar and D. C. Neckers, "Photochemistry of azobenzene-containing polymers," Chemical Reviews, vol. 89, no. 8, pp. 1915-1925, 1989.

[23] M. Mathews and N. Tamaoki, "Planar chiral azobenzenophanes as chiroptic switches for photon mode reversible reflection color control in induced chiral nematic liquid crystals," Journal of the American Chemical Society, vol. 130, no. 34, pp. 11409-11416, 2008.

[24] S. Velate, E. O. Danilov, and M. A. J. Rodgers, "Ultrafast dynamics of the azobenzene-coumarin complex: investigation of cooling dynamics measured by an integrated molecular thermometer," Journal of Physical Chemistry A, vol. 109, no. 40, pp. 8969-8975, 2005.

[25] L. Gagliardi, G. Orlandi, F. Bernardi, A. Cembran, and M. Garavelli, "A theoretical study of the lowest electronic states of azobenzene: the role of torsion coordinate in the cis-trans photoisomerization," Theoretical Chemistry Accounts: Theory, Computation, and Modeling (Theoretica Chimica Acta), vol. 111, no. 2-6, pp. 363-372, 2004.

[26] E. Luboch, E. Wagner-Wysiecka, Z. Poleska-Muchlado, and V. C. Kravtsov, "Synthesis and properties of azobenzocrown ethers with $\pi$-electron donor, or $\pi$-electron donor and $\pi$-electron acceptor group(s) on benzene ring(s)," Tetrahedron, vol. 61, no. 45, pp. 10738-10747, 2005.

[27] Y. Apeloig, Theoretical Aspects of Organosilicon Compounds in Organic Silicon Compounds, John Wiley \& Sons, New York, NY, USA, 1989.

[28] M. Geyer, O. Karlsson, J. A. Baus et al., "Si- and C-functional organosilicon building blocks for synthesis based on 4silacyclohexan-1-ones containing the silicon protecting groups MOP (4-methoxyphenyl), DMOP (2,6-dimethoxyphenyl), or TMOP (2,4,6-trimethoxyphenyl)," The Journal of Organic Chemistry, vol. 80, no. 11, pp. 5804-5811, 2015.

[29] B. Jung and P. Theato, "Chemical strategies for the synthesis of protein-polymer conjugates," Advances in Polymer Science, vol. 253, pp. 37-70, 2013.

[30] S. Y. Kim and J.-I. Hong, "Chromogenic and fluorescent chemodosimeter for detection of fluoride in aqueous solution," Organic Letters, vol. 9, no. 16, pp. 3109-3112, 2007.

[31] J. F. Rabek, "Photochemistry and photophysics IV," Pure and Applied Chemistry, vol. 64, pp. 1311-1317, 1991.

[32] K. Kuciński, P. Pawluć, B. Marciniec, and G. Hreczycho, "Highly selective hydrothiolation of unsaturated organosilicon compounds catalyzed by scandium(III) triflate," Chemistry - $A$ European Journal, vol. 21, no. 13, pp. 4940-4943, 2015.

[33] A. K. Franz and S. O. Wilson, "Organosilicon molecules with medicinal applications," Journal of Medicinal Chemistry, vol. 56, no. 2, pp. 388-405, 2013.

[34] R. A. Reddy, U. Baumeister, C. Keith, H. Hahn, H. Lang, and C. Tschierske, "Influence of the core structure on the development of polar order and superstructural chirality in liquid crystalline phases formed by silylated bent-core molecules: lateral substituents," Soft Matter, vol. 3, no. 5, pp. 558-570, 2007.

[35] A. Eremin and A. Jákli, "Polar bent-shape liquid crystals-from molecular bend to layer splay and chirality," Soft Matter, vol. 9, no. 3, pp. 615-637, 2013.

[36] R. Kieffer, M. Prehm, K. Pelz et al., "Siloxanes and carbosilanes as new building blocks for T-shaped bolaamphiphilic LC molecules," Soft Matter, vol. 5, no. 6, pp. 1214-1227, 2009.

[37] J. Garcia-Amorõs, H. Finkelmann, and D. Velasco, "Increasing the isomerisation kinetics of azo dyes by chemical bonding to liquid-crystalline polymers," Chemistry-A European Journal, vol. 17, no. 23, pp. 6518-6523, 2011.

[38] J. D. Roberts and M. C. Caserio, Basic Principles of Organic Chemistry, W. A. Benjamin, Menlo Park, Calif, USA, 1977.

[39] R. Dong, B. Zhu, Y. Zhou, D. Yan, and X. Zhu, "Reversible photoisomerization of azobenzene-containing polymeric systems driven by visible light," Polymer Chemistry, vol. 4, no. 4, pp. 912 915, 2013

[40] S. Balamurugan, G.-Y. Yeap, W. A. K. Mahmood, P.-L. Tan, and K.-Y. Cheong, "Thermal and photo reversible gel-sol transition of azobenzene based liquid crystalline organogel," Journal of 
Photochemistry and Photobiology A: Chemistry, vol. 278, pp. 1924, 2014.

[41] H. Murakami, A. Kawabuchi, K. Kotoo, M. Kunitake, and N. Nakashima, "A light-driven molecular shuttle based on a rotaxane," Journal of the American Chemical Society, vol. 119, no. 32, pp. 7605-7606, 1997.

[42] L. Pérez-García and D. B. Amabilino, "Spontaneous resolution, whence and whither: from enantiomorphic solids to chiral liquid crystals, monolayers and macro- and supra-molecular polymers and assemblies," Chemical Society Reviews, vol. 36, no. 6, pp. 941-967, 2007. 

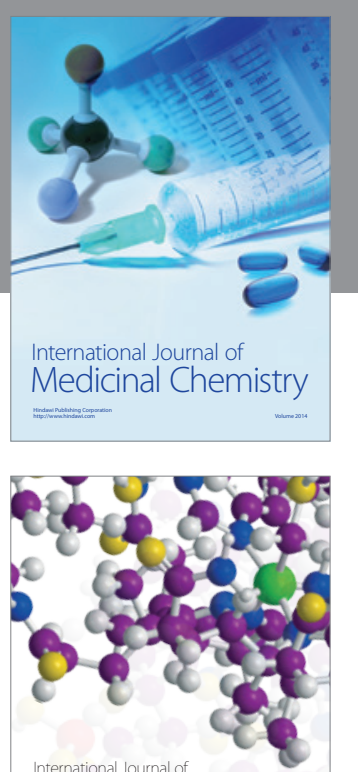

Carbohydrate Chemistry

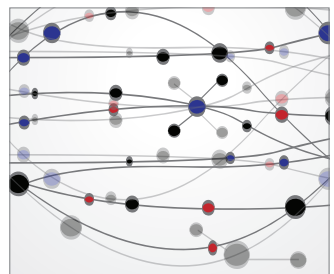

The Scientific World Journal
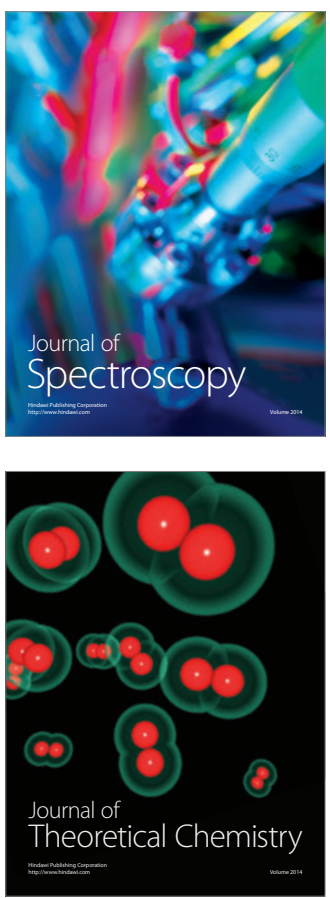
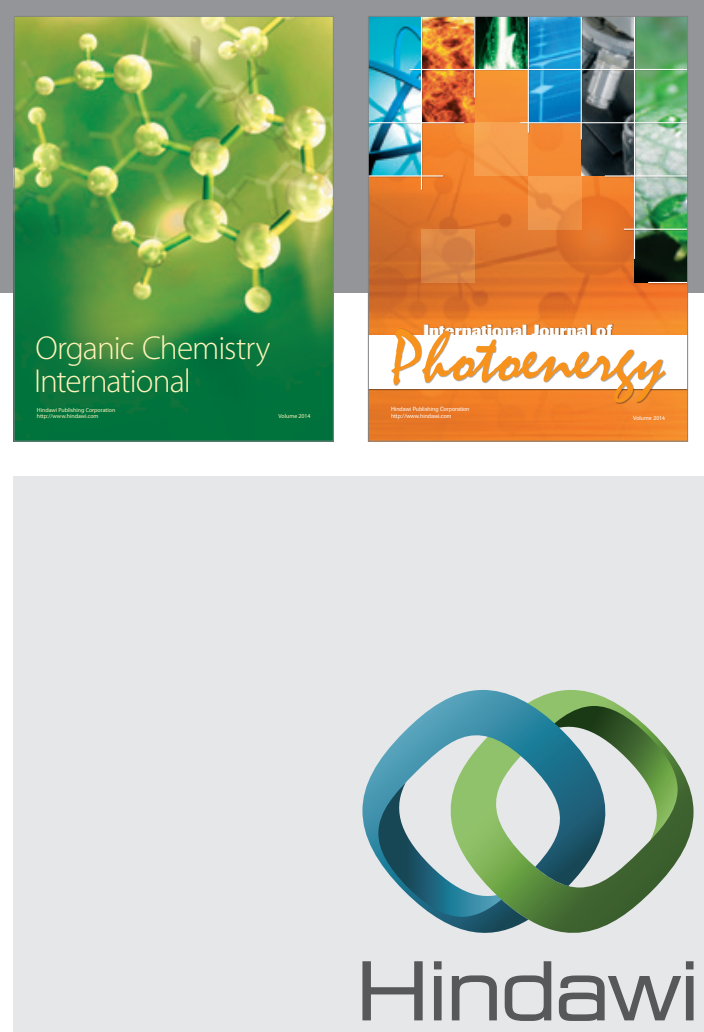

Submit your manuscripts at

http://www.hindawi.com

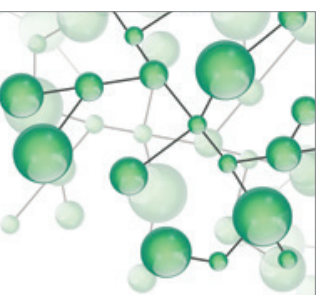

International Journal of

Inorganic Chemistry

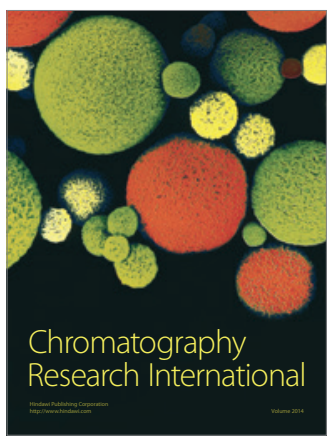

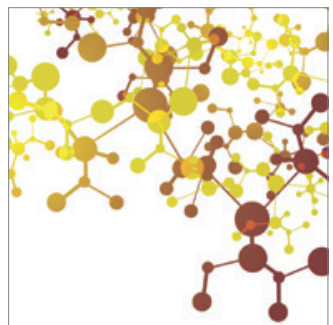

Applied Chemistry
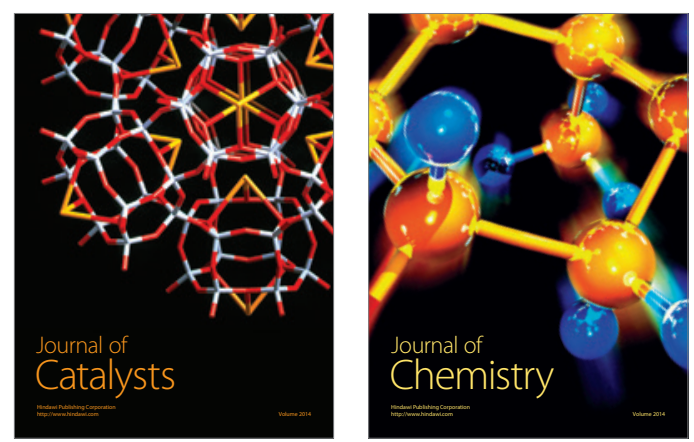
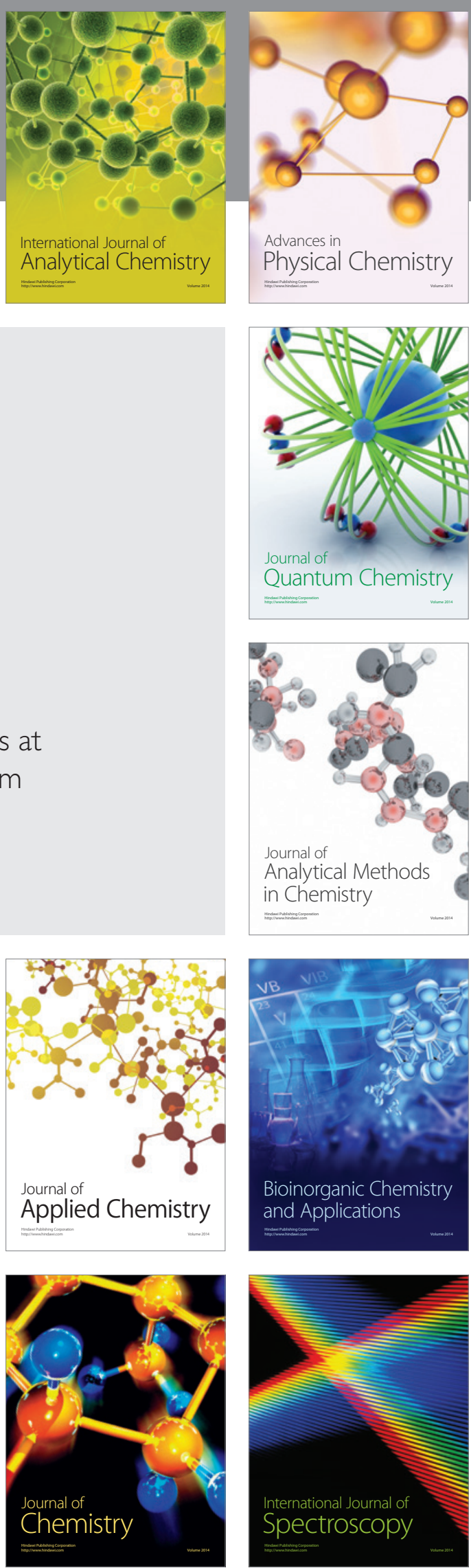